\title{
7.2 Об'єктивні та суб'єктивні ризики професійного вигоряння фахівця соціальної сфери
}

У найбільш загальному вигляді життєдіяльність людини пов'язана 3 сімейною сферою та професійною зайнятістю. Особливе місце займає сфера професійної діяльності, яка є визначальним фактором соціалізації, добробуту, самопочуття. Нераціональний підхід до організації роботи часто призводить до професійного вигоряння. Особливо це є актуальним, коли має місце робота психологічного характеру з людьми. Наслідками такого перенапруження можуть бути проблеми 3 фізичним і психічним здоров'ям. Соціальна, соціальнопедагогічна, соціально-психологічна діяльність має зазначені ризики.

Якщо підходити до поняття професійного вигоряння, то в узагальненому вигляді $[519$, с. $40 ; 520$, с. 12$]$ можна констатувати його як неспроможність виконувати професійні обов'язки на належному рівні внаслідок тривалого фізичного та/чи психічного перевантаження. Основною метою профілактики професійного вигоряння $є$ забезпечити дотримання індивідом норм у ставленні до себе і свого здоров’я, передбачених можливостями суспільного укладу і відносин.

Констатується, що особи, які пережили стан професійного вигоряння, мають певні відмінності у поведінці. Вони стають замкненими в собі, віддаленими від суспільних реалій. Іноді це набуває характеру дивакуватості, надмірної агресивності, ексцентричності. Опосередкований негативний вплив полягає в тому, що не реалізуються здібності, задатки людини. Протидії цьому немає через відсутність впливу формальних колективів, формування культури міжособистісних стосунків, розвиток позитивних нахилів, здібностей, інтересів [521, с. 39]. Інформаційне перенасичення, психологічна перевтома людини й перевантаження складають основу погіршення психічного, тому і зростає актуальність профілактики таких негативних явищ.

Констатація факту професійного вигоряння свідчить про неправильно визначені особистісні цінності як орієнтири життєдіяльності людини. Оскільки 
особистісні цінності формуються на основі соціальних, зроблено такі узагальнення щодо їх сутності та значення: це соціальний феномен, який існує в діалектичному сенсі суб'єкт-об'єкт, важливий фактор, що стимулює поведінку й вчинки особи та соціальних груп; цінності визначають ставлення людини до світу, самої себе, спрямовують їі розвиток [522, с. 171-173]. Життя людини та їі здоров’я визначено як найголовніші суспільні цінності. І особливо це стосується професійного вигоряння відповідно до динамічних умов суспільного розвитку, коли існують екологічне забруднення, відсутність фізичної активності як фону для фізичного здоров’я людини.

В основі профілактики має бути здатність обрати певну лінію поведінки, самостійно формулювати моральні обов’язки, вимагати від себе їх виконання, здійснювати самооцінку, самоконтроль [523, с. 18]. Зазначається багатоаспектність профілактики: «Якщо ми хочемо попередити відхилення у розвитку й поведінці особистості, то повинні перш за все створити такі умови, при яких охоплено було би всі сторони життєдіяльності, що є невіддільною частиною всього буття соціуму, проникнення в усі сфери суспільних відносин» [524, с. 41]. Отже, профілактику професійного вигоряння (попередження, запобігання) варто розглядати як цілеспрямований процес організації i здійснення комплексу профілактичних заходів, спрямованих на забезпечення соціально-психологічного розвитку i життєдіяльності [525, с. 212]. Суб’єктивність профілактики полягає у ціннісному орієнтуванні індивіда або ж у дотриманні соціальних норм, що відповідають соціальним цінностям. Це має бути основою підходу до професійної діяльності, а у профілактиці професійного вигоряння це передбачає визначення такої лінії поведінки, яка б забезпечила високий рівень життєдіяльності.

Професійне вигоряння є наслідком порушення норм поведінки. Критеріями відхилень від норми виділяють: а) статистичний (норма для будь-якого явища шляхом підрахунку частоти, 3 якою вона зустрічається); б) якісно-кількісна оцінка поведінки (за ступенем вираження та рівнем загрози для життя); в) психопатологічний (медичний); г) соціально-нормативний (рівень соціальної 
адаптації індивіда) [520, с. 11]. Причиною професійного вигоряння може бути і гіпервідповідальність людини як члена колективу. Вирізняють чотири типи відповідальності: інтегральну (загальнолюдські норми і вимоги суспільства стали для індивіда особистісно значущими), групову (орієнтація на референтну групу, на досягнення вузькогрупових цілей), вузькоособисту (орієнтовану на особисті, корисливі інтереси), невизначену (або несправжню, удавану). Аналогічно до типів соціальної відповідальності, вирізняють чотири групи асоціальної [521, с. 3]. У такому ракурсі необхідно розглядати зв'язок віктимної і девіантної поведінки [526, с. 109]. Тобто професійне вигоряння залежить передусім від відповідального ставлення до себе самого суб'єкта професійної діяльності.

Причини професійного вигоряння можна диференціювати за характером детермінації:

•серед детермінант, що впливають на ставлення до себе і професійної діяльності, виділяють ті, що лежать в основі статевого диморфізму, стану здоров'я, самопочуття, захворювань, зокрема, враховуються деякі біологічні чинники, які можуть негативно впливати на психіку, що призводить до неадекватної поведінки [527, с. 115];

•широке коло проблем викликає екологічне забруднення навколишнього середовища; це має наслідки у погіршенні фізичного, а відтак і психічного здоров’я, підвищенні агресивності, зниженні впевненості у собі, підвищенні рівня тривожності, кількості пережитих стресів та посиленні дії стресових чинників (є свідчення про дезадаптаційний вплив погіршення співвідношення екологічної якості міського середовища з біологічними потребами людини [528, c. 22];

•серед психологічних детермінант, що призводять до професійного вигоряння, називають агресію, агресивність у стосунках людей; різні підходи до пояснення агресивності аналізує Охрімчук Р. [526, с. 4-7].

Фахівці соціальної сфери - це переважно жінки. Оскільки сьогодні особи жіночої статі дедалі частіше заявляють про свою рівноправність, на них 
покладено багато обов'язків і вдома, і на роботі. Проте це часто приводить до психічного перевантаження людини і прояв неврозів.

Щоб уникнути відхилень, потрібно вміти регулювати свої бажання, породжені суспільною думкою, й можливості, які дає нам фізичний та/чи психічний ресурс організму. Соціальна стратифікація, що панує у суспільних відносинах, створює перенапруження, коли людина прагне досягти більшого дорогою ціною здоров’я. Окрім того загальновідомо, що рівень навантаження неоднаковий серед різних вікових груп населення, чоловіків і жінок, людей різних професій.

Нами проведено анкетування серед фахівців соціальної сфери щодо стану професійного вигоряння серед них. Взято до уваги відповіді 22 респондентів, які працюють на посадах в органах державної виконавчої влади і місцевого самоврядування (м. Тернопіль, Тернопільська область). У табл. 1 наведено статистичні дані стосовно факторів впливу на професійне вигоряння фахівця, а також їх динаміка.

Таблиця 1

Фактори і динаміка впливу на професійне вигоряння (за свідченнями фахівців соціальної сфери)

\begin{tabular}{|c|c|c|c|}
\hline Професійні компоненти & $\begin{array}{c}\text { Значний вплив } \\
(\boldsymbol{\%})\end{array}$ & $\begin{array}{c}\text { Посередній } \\
\text { вплив } \\
(\boldsymbol{\%})\end{array}$ & $\begin{array}{c}\text { Незначний } \\
\text { вплив } \\
\mathbf{( \% )}\end{array}$ \\
\hline $\begin{array}{c}\text { Характер } \\
\text { роботи }\end{array}$ & 21,2 & 42,0 & 36,8 \\
\hline $\begin{array}{c}\text { Терміни виконання } \\
\text { професійних обов'язків }\end{array}$ & 42,6 & 34,6 & 22,8 \\
\hline $\begin{array}{c}\text { Внутрішньо- колективні } \\
\text { стосунки }\end{array}$ & 63,4 & 21,4 & 14.8 \\
\hline $\begin{array}{c}\text { Професійна здатність } \\
\text { виконувати обов'язки }\end{array}$ & 63.4 & 12,6 & 23,0 \\
\hline
\end{tabular}

Наведені статистичні дані переконують у тому, що внутрішньо колективні стосунки й здатність виконувати професійні обов'язки мають найбільш вплив на психоемоційний стан особи та рівень іiі професійного вигоряння. Це засвідчує, що мають значення як соціально-організаційна, так і психолого-педагогічна складова профілактики. 
Отже, в основі професійної діяльності має бути забезпечення умов для цього. Проте колективна співпраця, крім того, що має переваги, наділена й негативними рисами. У табл. 2 представлено ті показники колективного неблагополуччя, що безпосередньо впливають на професійне вигоряння індивіда як члена колективу.

Таблиця 2

Порівняльний аналіз показників колективного неблагополуччя, що мають вплив на професійне вигоряння

\begin{tabular}{|c|c|c|c|}
\hline $\begin{array}{l}\text { № } \\
\text { 3/II }\end{array}$ & Показники & $\begin{array}{c}\text { Особи, які не } \\
\text { зазнали } \\
\text { професійного } \\
\text { вигоряння } \\
\text { (\%) }\end{array}$ & $\begin{array}{c}\text { Особи, які } \\
\text { пережили } \\
\text { стан } \\
\text { професійного } \\
\text { вигоряння } \\
\text { (\%) }\end{array}$ \\
\hline 1.1. & $\begin{array}{l}\begin{array}{l}\text { Проблеми } \\
\text { культури }\end{array} \\
\end{array}$ & 16,7 & 65,3 \\
\hline 2.2 . & $\begin{array}{l}\text { Невдоволеність психологічною атмосферою, яка } \\
\text { панує в колективі }\end{array}$ & 42,5 & 88,8 \\
\hline 3.3 . & $\begin{array}{l}\text { Наявність конфліктних ситуацій, сварок, } \\
\text { інтриганства }\end{array}$ & 15,4 & 92,2 \\
\hline 4.4 . & $\begin{array}{l}\text { Відсутність чи проблеми міжособистісного } \\
\text { спілкування в колективі, поділ на групи }\end{array}$ & 25,8 & 74,9 \\
\hline 5.5 . & $\begin{array}{l}\text { Низький рівень взаємодопомоги і підтримки, } \\
\text { небажання підтримувати дружні стосунки }\end{array}$ & 34,2 & 86,3 \\
\hline 6.6 . & $\begin{array}{l}\text { Відсутність покарань за провини, реагування на } \\
\text { негативну поведінку колег, контролю за } \\
\text { суб’єктивними чинниками }\end{array}$ & 30,1 & 96,0 \\
\hline 7.7. & Відсутність перспектив розвитку колективу & 14,8 & 67,7 \\
\hline 8.8 . & $\begin{array}{l}\text { Відсутність умов особистісного розвитку й } \\
\text { формування }\end{array}$ & 45.8 & 95,5 \\
\hline 9.9. & $\begin{array}{l}\text { Відсутність заходів профілактики професійного } \\
\text { вигоряння }\end{array}$ & 33,4 & 77,5 \\
\hline
\end{tabular}

Так, особи, які пережили стан професійного вигоряння, мають значно глибші психоемоційні порушення. Їхній професійний досвід характеризується значними негативним досвідом й переконаннями. У їхньому житті зазнали деформації позитивні корпоративні соціальні зв’язки, що може призвести до відхилень в інших сферах: сімейній, особистісній, духовно-емоційній. Тобто це викликає і інші деформації. Названі компоненти рівноваги становища особи базуються на відсутності єдиної основи - тепла, любові, уваги, турботи, 
підтримки, піклування, взаєморозуміння. Не знайшовши їх, людина черствіє, стає байдужою не тільки до своїх проблем, переживань, а й до відчуттів інших людей.

Втрата життєвих орієнтирів, відсутність позитивних емоцій, душевна черствість з часом стають постійними, деформуючи особистість, роблячи iㅣ поведінку якщо не соціально небезпечною, то неадекватною. Компенсацією позитивних емоцій у життедіяльнтості часто стають адиктивні прояви. Такі, як пияцтво, алкоголізм, тютюнопаління, інтернет-залежність, комп’ютерна залежність та інші види адикцій. У табл. 3 наводимо статистичні дані щодо оцінювання наявних ризиків професійного вигоряння фахівцями різних соціальних структур для порівняння.

Таблиця 3

\section{Розподіл відповідей фахівців соціальної сфери}

щодо оцінювання наявних ризиків професійного вигоряння

\begin{tabular}{|c|c|c|c|c|}
\hline \multicolumn{5}{|c|}{ Фахівці соціальної сфери } \\
\hline $\begin{array}{c}\text { Працівники } \\
\text { центру } \\
\text { соціальних } \\
\text { служб } \\
(\%)\end{array}$ & $\begin{array}{c}\text { Працівники } \\
\text { відділу } \\
\text { у справах сім'i } \\
\text { та молоді } \\
(\%)\end{array}$ & $\begin{array}{c}\text { Працівники } \\
\text { служби у } \\
\text { справах } \\
\text { дітей } \\
(\%)\end{array}$ & $\begin{array}{c}\text { Працівники } \\
\text { центру } \\
\text { зайнятості } \\
\text { населення } \\
(\%)\end{array}$ & $\begin{array}{c}\text { Педагоги } \\
\text { загально } \\
\text { освітньої } \\
\text { школи } \\
(\%)\end{array}$ \\
\hline 18 & 21 & 20 & 26 & 24 \\
\hline 55 & 58 & 64 & 48 & 54 \\
\hline 22 & 21 & 8 & 24 & 22 \\
\hline 5 & - & - & 2 & - \\
\hline- & - & 8 & - & - \\
\hline
\end{tabular}

Як видно $з$ табл. 3: майже всі, крім 8 осіб, визнали факт професійного вигоряння різного ступеня; переважна більшість респондентів оцінює здатність виконувати професійні обов'язки переважно добре, проте відсутність абсолютної відповіді також свідчить про наявні ризики; переважною мірою наявність ризиків професійного вигоряння оцінюють посередньо.

Очевидно, що професійне вигоряння зумовлене різними факторами, серед яких на основі опитування, статистичних даних, експертного оцінювання проведеного експериментального дослідження можна виділити такі: соціальні й організаційні умови функціонування колективу, законодавче й нормативно- 
організаційне забезпечення процесу праці; індивідуальні та особистісні якості особистості, стресостійкість, мотивація діяльності; відповідність якостей і рис особистості вимогам обраної професії, професійна компетентність; здатність працювати у колективі, вміння враховувати думки i позиції інших, комунікабельність; наявність життєвого, професійного досвіду; психологічна сумісність окремих членів колективу; вміння контролювати ситуацією в колективі з боку керівництва; корпоративна культура, наявність спільних інтересів і заходів, зацікавленість у розвитку й процвітанні колективу.

Теоретичний аналіз й експериментальне дослідження проблем, що стосуються професійного вигоряння, свідчать про наявність ризиків у професійній діяльності фахівців різних соціальних структур. Тобто, це залежить як від об'єктивних факторів (суспільні негаразди), так і від суб'єктивного ставлення індивіда до себе і свого психічного та фізичного здоров'я: від того, як налаштовує себе фахівець, його мотивація і вміння організувати правильно себе, свій життєвий простій, свою діяльність.

Надалі варто приділити увагу тому, що це проблема не стільки суспільна, колективна, а індивідуальна. Потребують теоретичного аналізу й практична перевірка діагностичного інструментарію, ефективності заходів профілактики стосовно професійного вигоряння індивіда. 